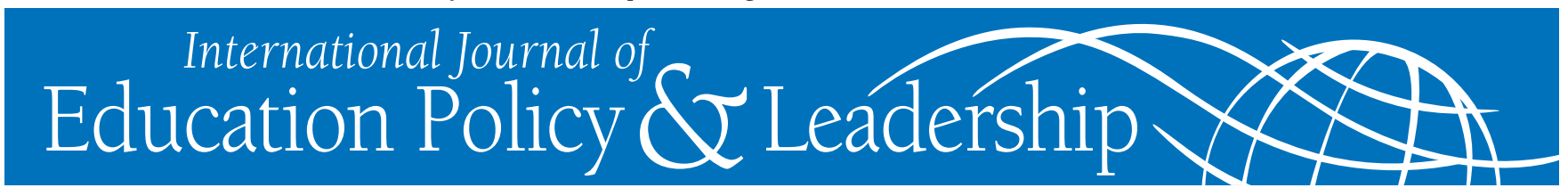

\title{
Countering School Bullying: An Analysis of Policy Content in Ontario and Saskatchewan
}

\author{
GinetTe DiAne RoberGE \\ École des sciences de l'éducation \\ French School of Education \\ Laurentian University
}

\begin{abstract}
The incidence of extreme school violence as a direct consequence of bullying among peers, exacerbated by vast media attention, has caused educational institutions worldwide to put bullying intervention and prevention strategies into operation. This study focused on an overview of two provincewide antibullying incentives in the Canadian provinces of Ontario and Saskatchewan, and an analysis of the quality of their respective antibullying policies. An itemized list of beneficial practices for bullying intervention and prevention originated from Smith, Smith, Osborn and Samara (2008)'s scoring scheme. The scoring scheme was adapted to the current study by linking research-based program elements that have been found to be effective in reducing school bullying to a content analysis of both provincial frameworks. The final scoring scheme comprised a total of 39 criterions, divided into five categories: Defining Bullying Behaviors, Establishing a Positive School Climate, Disseminating, Monitoring and Reviewing Policy, Reporting and Responding to Bullying, and Involving the Broader Community. Results showed that policies contained a total average of $60 \%$ of the criterions in Ontario, and 59\% in Saskatchewan. The conclusion of this study observes from policy lenses key essentials of bullying intervention and prevention initiatives in elementary and secondary educational settings. Recommendations are proposed to bridge the gap between areas that have received extensive attention and areas that have received less treatment in bullying intervention and prevention endeavors, using the content of Ontario and Saskatchewan policies as a basis for discussion.
\end{abstract}

Roberge, G. D. (2011). Countering school bullying: An analysis of policy content in Ontario and Saskatchewan. International Journal of Education Policy and Leadership 6(5).

Bullying has been discovered, to varying extents, in every school in which related studies have been conducted (Beaty \& Alexeyev, 2008; Hamarus \& Kaikkonen, 2008; Rigby, 2008). In light of public awareness of the potentially long-term affects of prolonged exposure to negative childhood peer relationships, numerous bullying intervention and prevention policies have been developed in educational settings around the globe. There is general consensus in the midst of varied professional opinions on the bullying phenomenon that intervention should occur beyond individual incidents of discord between peers to include parents, staff, administrators, community supporters, as well as policymakers (Olweus,
2004; Rigby, Smith, \& Pepler, 2004; Swearer \& Doll, 2001). Extant research has confirmed, nevertheless, that many programs and policies with aims to reduce bullying in schools have achieved marginal levels of success (Craig \& Harel, 2004; Pepler, Craig, O'Connell, Atlas, \& Charach, 2004; Rigby, 2002).

Researchers attribute the common barriers to the success of antibullying policies to numerous potential causes. First, it is believed that bullying may be underreported due to pupil fears of further reprisal by their peers or by authority (O'Moore \& Minton, 2005; Rigby, 2008). Other researchers believe that the judiciary structure of zero tolerance policies may actually hinder success rates because they neglect to

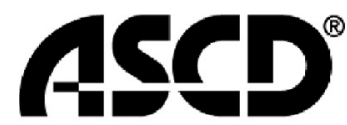

LEARN. TEACH. LEAD.
SIMON FRASER UNIVERSITY THINKING OF THE WORLD

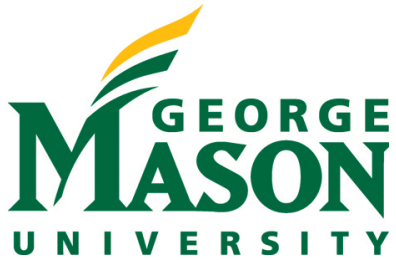


take into consideration individual circumstances, environmental factors, and personality dynamics, opting rather for homogenous resolutions to bullying (Bloom, 2008; Coloroso, 2002; Daniel \& Bondy, 2008). Another common supposition is that bullying is not often readily observed by adults supervising the classroom and the school grounds, which makes intervention problematic (Espelage \& Asidao, 2001; Swearer \& Doll, 2001).

Most Canadian provinces, as well as the territory of Yukon, have developed safe schools frameworks that focus on addressing issues of bullying in schools. Many of these frameworks include extensive educational resources for parents, students, and educators. Ontario and Saskatchewan are two Canadian provinces whose governments have mandated antibullying action through a framework for policy implementation. This mandate created an ideal context for the study of the quality of the ensuing antibullying policies in both provinces, which was the reason for the selection of these provincial policies in the current study.

The purpose of this study was twofold. One objective was to analyze the content of school board and division antibullying policies in both provinces in order to establish the extent of effective bullying intervention and prevention practices contained within the documents. An extension of the first objective was to initiate discussion on ways to bridge the gap between policy content and effective antibullying practices, using Ontario and Saskatchewan antibullying policy content as a starting point for future research.

\section{Contextual Framework}

Jurisdiction for Canadian education is overseen by the provincial government. Matters of curriculum and instruction are therefore governed by provinces or territories. Canada has two official languages: French and English. The term school board refers to educational offices in Ontario who represent the administrative authority over geographical locations in the province. Similarly, the term school division refers to the equivalent educational authority in Saskatchewan. All provinces and territories in Canada have distinct procedures on educational matters. These procedures are fundamentally linked to their individual provincial preoccupations. In Ontario and
Saskatchewan, the provincial governments have mandated antibullying action through the elaboration of a model framework for the development of antibullying policies by their respective school boards or divisions. The provincial bullying intervention and prevention strategies in Ontario and Saskatchewan are briefly described below.

\section{The Ontario Bullying Policy/Program Memorandum (PPM 144)}

The Ontario Ministry of Education is the governing body of publicly funded elementary and secondary schools in Ontario. The Ontario Ministry of Training, Colleges, and Universities, oversees postsecondary education. The province of Ontario currently operates four school systems: French- and Englishlanguage catholic (or separate) school systems, as well as French- and English-language public school systems. School boards must adhere to the guidelines set forth by the provincial government concerning matters such as curriculum and instruction, regulations concerning grading standards and student achievement, as well as funding for educational programming and specific allocations. Ontario currently has 72 district school boards and 33 school authorities that represent geographically isolated schools with a small number of students or hospitals with an educational focus (Ontario Ministry of Education, n.d.).

Policy/Program Memoranda in Ontario consists of numbered instructions presented to district school boards and school authorities to summarize the Ministry of Education's expectations for implementation of ministry policies and programs (Ontario Ministry of Education, n.d.). On October 4, 2007, the Ontario Ministry of Education introduced a PPM, named PPM 144, which provided a framework for school boards and authorities to either develop antibullying policies or to modify their existing policies to respect the structure of the communication. PPM 144 was the result of a report created by a Safe Schools Action Team appointed by the Minister of Education. The recommendations were based on the panel's personal and professional experiences with bullying, as well as on extensive consultations with stakeholders across Ontario. The initial PPM required all school boards in Ontario to have bullying intervention and 
prevention policies in place by February 1, 2008. The PPM was later amended in 2009, with all school boards required to have revised policies and procedures in place by February 1, 2010. The revised PPM further requires school boards to draw upon research-based practices to improve their existing policies. The framework is meant to provide direction in the development of these policies. Under the guidance of the PPM, school boards are required to carry out a number of bullying intervention and prevention actions, such as: creating a positive school climate, using a prescribed definition of bullying, ensuring the respect of student diversity, incorporating intervention and prevention strategies, training members of the school community, establishing performance indicators for monitoring and reviewing of bullying policies, and creating safe school teams to address issues of student safety.

\section{The Saskatchewan Antibullying Strategy (SABS)}

The Saskatchewan Ministry of Education has the same authority over elementary and secondary educational issues in the province as the Ontario Ministry of Education. In contrast to Ontario's provincial government, which operates four school systems, three sectors of the Ministry of Education in Saskatchewan oversee English-language education, French-language education, as well as Métis and First Nations education. This province is more sparsely populated than Ontario. As such, in Saskatchewan, there are currently 29 public or catholic school divisions that oversee specific geographical districts. The Education Act of 1995 stipulates that the daily operations of schools, including student behavioral issues, are the responsibility of boards of education.

Saskatchewan Learning is the administration that sets legislative and policy direction for the provincial educational system. The SABS was developed in 2005, and the accompanying model policy published in 2006 (Saskatchewan Learning, 2005; 2006). This strategy refers to the Education Act (1995), core curriculum related to interpersonal and personal development, and incorporates the subsequent development of a Caring and Respectful Schools Policy (Saskatchewan Learning, 2006). The Caring and Respectful Schools document is a model which includes guidelines for the elaboration and implementation of antibullying policy by school divisions. The SABS requires all school divisions to have an antibullying policy with specific endeavors to respond to bullying: a statement that bullying will not be tolerated, a definition of bullying, a statement describing the necessity of a positive learning environment, a delineation of responsibilities for all adults who interact with students in the schools, and parameters to review bullying action plans. The SABS also endeavors to provide funding for bullying intervention and mandates the creation of school teams to address issues of student safety. Finally, on a higher administrative echelon, the SABS outlines specific measures to be undertaken at the legislative level to ensure that community partners provide support to schools in their bullying intervention and prevention actions (Saskatchewan Learning, 2005).

\section{Policy Content and the Prevalence of School Bullying}

Research has uncovered varying correlations between the worth and content of school bullying policies and the frequency of bullying in schools. Woods and Wolke (2003) studied the quality of bullying intervention and prevention policies and their association to bullying frequency. Their research findings imply little correlation between the rate of recurrence of manifestation of bullying behaviors among students and the content of policies. The outcome of their study revealed that while schools with more detailed policies had slightly lower rates of bullying, these schools also reported higher rates of social-relational bullying. Conversely, this occurrence could be attributed to a pre-test, post-test effect identified by some researchers (Pepler et al., 2004; Rigby et al., 2004) in which students who are exposed to bullying education sometimes self-identify as being victims of bullying as a result of a new awareness that is created through this learning experience. This awareness has caused research results to show higher rates of bullying in subsequent school climate assessments, whereas researchers stipulated that victims of bulling may have simply not ascribed to their experience the label of bullying during the initial assessment phase. For their part, Soutter $\&$ McKenzie (2000) affirm that implementing effective antibullying policies 
promotes change. Swearer, Limber, \& Alley (2009) share this belief in their indication that a wellfounded and developed antibullying policy not only sets the groundwork for communicating expectations of behavior, but also underlines the seriousness of bullying for the school community.

On the other hand, the complexities of observable behaviors in bullying situations can render intervention measures difficult to carry out when developing and implementing policy. One common challenge exemplified by research is that bullying often occurs in areas on school property where there is little or no adult supervision. This challenge could complicate school yard interventions and impinge on the effectiveness of policies meant to reduce bullying (Swearer \& Doll, 2001). Another finding from Glover, Cartwright, Gough, and Johnson (1998) reveals that policy creation affects the school experience for pupils. They advise that the nature of the fundamental school culture in practice is more influential than existing policy. Furthermore, Smith et al. (2008) state that while school antibullying policies are a compulsory legal requirement in England, their sample of policies neglected treatment in a number of key areas. In addition, the personal nature of interpretation of policy can cause a disparity in individual implementation of the frameworks by school boards and divisions (Glover et al., 1998).

As well, numerous bullying intervention programs of comparable structure have been attempted and have yielded dissimilar results when undertaken in different settings (Rigby et al., 2004). In this study, it is noteworthy to mention that despite the presence of provincial frameworks, school boards and divisions still had flexibility for regional adaptation of the PPM and SABS by tailoring their policies according to factors such as regional needs and state of affairs, cultural needs, demographics, as well as the availability of community and board resources to support bullying intervention and prevention actions (Ontario Ministry of Education, 2009; Saskatchewan Learning, 2006).

\section{Effective Research and Evidence-Based An- tibullying Practices}

Researchers have reported important considerations of antibullying policy development. First, Swearer et al. (2009) delineate ten best practices to include in bullying policy, namely: changing the school climate, training staff, assessing bullying behaviors, including staff, parents and students in antibullying action, creating safe school teams, establishing clear rules and consequences, increasing supervision, providing individual support, including classroom time for social-emotional learning, and finally, monitoring and continuing antibullying efforts. The DfES (2002) Don't suffer in silence publication stipulates that antibullying policy should establish prevention and intervention measures, as well as the documentation of bullying incidents by a member of the school community. The publication further suggests the importance of disseminating policy, of consulting with members of the larger community for policy development and implementation, as well as regularly monitoring and revising the policy. The PPM and SABS propose similar policy content, but further suggest the creation of groups responsible for student safety within the schools.

Smith et al. (2008) further indicate that policies should explicitly define bullying because it can be confounded on a continuum of other violent behaviors, such as harassment and aggression. Bullying is distinguished from aggression and harassment in the literature as being an unprovoked behavior that is persistent and that includes an imbalance of power between the individual responsible for bullying and the victim (Olweus, Limber, \& Mihalic, 1999; Ontario Ministry of Education, 2009; Swearer et al., 2009). The Ontario Ministry of Education (2009) further states in the PPM that bullying includes a willful action that should be reasonably known to harm. Different forms of bullying are also recognized, as noted in the scoring scheme: physical bullying, verbal bullying, cyberbullying, relational bullying, as well as bullying of a sexual nature or bullying that is based on race, gender, sexual orientation, religious beliefs, or physical or intellectual disabilities.

Research has shown that bullying behaviors hit their highest point during middle school years (Swearer et al., 2009). The individuals typically involved in bullying incidents are the perpetrator of bullying, the recipient of the act of bullying, as well as the impartial bystander. The PPM and the Smith et al. (2008) frameworks require specific interventions to assist all three groups. Furthermore, these frame- 
works both require sanctions that are adapted to the age of the perpetrator, to the internal and environmental circumstances of the perpetrator, as well as to the nature and severity of the bullying incident.

Finally, Caruso (2009) cautions that policies should avoid referring to specific groups as being potential victims of bullying to avoid an unwitting omission, and that policy language should be general and broad to cover different possibilities. In contrast, the Report of the House of Commons Education and Skills Committee on Bullying (House of Commons, 2007) states that while flexibility for individual adaptation of antibullying policies is beneficial (as afforded by both the PPM and SABS), this should be undertaken in conjunction with clear guidance on the development of effective policies as well as minimal standards of expectations of policy content. The implications are that establishing clearly delineated best practices for bullying intervention when developing policy remains a complex and multifaceted process.

\section{Method}

\section{Sample}

School boards and divisions in Ontario and Saskatchewan generally publish policy manuals for dissemination to the public, parents, stakeholders, and members of the community. Canada's two official languages are French and English, thus some boards and divisions operate in English while others operate in French. Policy documents were obtained in both languages. An initial search was conducted of all board and division policy manuals in order to locate antibullying policies. Documents were considered only if the words "bullying" or "intimidation" (the French equivalent in the case of French policy documents) were found in the policy title. Administrators of boards or divisions that did not have a publicized antibullying policy were contacted directly. Of 72 school boards in Ontario, 56 antibullying policies were obtained, which constitutes a response rate of $79 \%$. Of 29 school divisions in Saskatchewan, fifteen policies were obtained, but only 8 antibullying policies were considered because 7 policies described variations of harassment rather than bullying. In light of the fact that bullying and harassment were determined to be equivocal by the researcher, as is described below, only the antibullying policies were considered. This constitutes a response rate of $52 \%$, with $27 \%$ viable policies for the purposes of this study.

\section{Elaboration and Validation of Instrument}

An itemized list of criterions was designed by the researcher to analyze policy content. The original list of criterions was adapted from the content analysis of Smith et al. (2008) but required modification. For example, their content analysis was developed in England and inspired by the DfES (2002) Don't Suffer in Silence publication. The policies analyzed in the Smith et al. (2008) study were also not necessarily limited to policies that had the words "bullying" or "intimidation" in the title, since other documents were considered if provided by schools and identified as documents of guiding principles for bullying. Smith et al. also analyzed individual school policies whereas this study focused on board and division policies that oversee governance of groupings of numerous schools. The criterion list was consequently modified to include elements from both the PPM and SABS, which are the Canadian equivalents of the Don't Suffer in Silence publication, as well as research findings of beneficial antibullying practices as reported in the literature.

In order to develop the initial scoring scheme, the researcher analyzed the content of the Smith et al. (2008), PPM, and SABS policy development frameworks using Skerrett's (2009) documentary analysis strategy. This involved a thorough and repeated individual reading of the documents, which were then coded and analyzed. A list of themes representing main categories in all three documents was elaborated separately, and sections of text were assigned to the main categories for the development of sub-categories. Once category lists and sub-sections were developed for all three documents, the three resulting criterion lists and theme lists were combined and redundant categories were removed. A new analysis of the PPM was conducted upon its revision (Ontario Ministry of Education, 2009), and the scoring scheme remained unaffected. Extant research was also considered to complete the scoring scheme when conflicting statements arose. 
The researcher first discussed the scoring scheme with the group of coders, who provided input and suggestions to strengthen the content analysis. An initial pilot test of the scoring scheme was undertaken by analyzing 7 antibullying policies from a province not considered in this study in order to establish scoring standards and to improve the criterion list. Subsequent modifications to the content analysis were then made. For example, Smith et al. (2008) seemed to attribute the same meaning to the terms "bullying" and "harassment". A review of the literature revealed a distinction between bullying and other aggressive behaviors, being that bullying includes an imbalance of power and involves willful intent to harm (Soutter \& McKenzie, 2000; Swearer et al., 2009). Student-to-student harassment policies were consequently excluded from the study due to the possible divergence in nomenclature surrounding the two terms. The term "harassment" was also removed from the criterion list.

Smith et al. also considered bullying outside of school grounds. The PPM mentioned activities occurring outside of school property, and SABS omitted mention of this form of bullying. A review of the literature revealed that bullying most often occurs on the way to and from school or in areas with little or no adult supervision (Espelage \& Asidao, 2001; Swearer $\&$ Doll, 2001) therefore a criterion was included to consider the possibility.

Smith et al., PPM, and SABS also noted preventative bullying measures, though the SABS document itself did not clarify nor provide examples. A further review of the literature was carried out in order to identify bullying prevention measures that should be included in policy, such as establishing a collaborative school climate and promoting positive behaviors, leadership, and healthy relationships (Swearer et al., 2009). Nonetheless, where Smith et al. attributed a category to bullying prevention, preventative measures were placed in the category of "Reporting and Responding to Bullying Behaviors" in the scoring scheme, as the PPM and SABS did include some of the preventative measures discovered in the literature without necessarily attributing them the title of bullying prevention.

Next, the original list of criterions necessitated the definition of related bullying behaviors such as verbal bullying and physical bullying. The pilot test revealed, however, that many policies simply enumerated different types of bullying with examples, and this was found to be sufficient due to the generic nature of policy language as reported in the literature (Caruso, 2009).

As a final point, a search of policy manuals in Ontario and Saskatchewan revealed that bullying between an adult and student as well as bullying between two adults are often considered in policies that are separate from antibullying policies (ex. workplace harassment policies, workplace bullying policies, or sexual harassment policies). In most cases, the nature of the intervention measures and mediation processes is different than those that are utilized to deal with bullying between peers. Consequently, only student-to-student bullying policies were considered in the study. A criterion from the Smith et al. (2008) framework that required policies to define bullying by teachers was removed from the scoring scheme because there was the possibility of this contingency being considered in alternate school board or division policies.

\section{Data Analysis}

To verify inter-rater reliability of the scoring scheme, two additional coders participated in the content analysis. One coder was given a random sample of 10 policies before the analysis. A second coder analyzed the same sample of policies after the analysis of all policies by the researcher. Percentage of agreement was calculated and reflected 100\% agreement in 26 categories, $90 \%$ agreement in eight categories, $80 \%$ agreement in four categories, and $70 \%$ agreement in one category. Cohen's Kappa (1960) was calculated where criterions were found to have less than $100 \%$ agreement in order to allow for the consideration of the percentage of agreement expected by chance. This formula allowed the researcher to calculate Cohen's Kappa: k=(Po-Pc) / (1-Pc). Kappa was 0.9 in eight categories, 0.6 in four categories, and 0.2 in one category. The lowest scoring category has been identified $\left(^{a}\right)$ on the scoring scheme.

Final scoring of policies was effected in accordance to the policy mentioning the criterions, and the extent to which schools could potentially adapt the criterions. Where a criterion was mentioned within a policy, the researcher ascribed a score of 
one (1) on the scoring scheme for that criterion. Where an item was omitted from a policy, the school board policy received a score of zero (0) for that criterion. In order to analyze the content of French policies the researcher elaborated a direct translation of the itemized list of criterions in French. Results were later conjointly tabulated in order to obtain total scores that comprised all provincial policies.

\section{Results}

The itemized list of criterions had face validity (Smith et al. 2008). There was no pre-determined expectation of strong internal reliability within the five categories and the individual criterions. The flexibility offered to school boards and divisions by their provincial governments in the individual adaptation of the PPM and SABS in antibullying policies founded the presumption that scoring high in one category would reflect the board's individual regional adaptation of framework principles rather than the likelihood of scoring high on a criterion from the same category. Table 1 (below) summarizes the level of criterion content in Ontario and Saskatchewan policies. The five main categories and accompanying criterions developed as a result of the analysis of the Smith et al. framework, the PPM, and the SABS are represented. Mean scores and standard deviations for every category are presented in bold. The number of school boards and divisions that included specific antibullying criterions is also represented within the table. Results are represented for both Ontario and Saskatchewan, respectively.

Table 1: Antibullying Content (mean in bold, standard deviation in brackets) in Ontario and Saskatchewan School Board and Division Policies

\begin{tabular}{|c|c|c|c|c|}
\hline \multirow[t]{2}{*}{ Criterion } & \multicolumn{2}{|c|}{ Ontario $(n=56)$} & \multicolumn{2}{|c|}{ Saskatchewan $(\mathrm{n}=8)$} \\
\hline & \# of items & Mean & \# of items & Mean \\
\hline Definition of Bullying Behaviors & 33 & 0.59 & 4.5 & 0.56 \\
\hline (12 criterions) & $(11.09)$ & $(0.20)$ & $(2.02)$ & $(0.25)$ \\
\hline 1. The policy includes an overall definition of bullying. & 51 & 0.91 & 7 & 0.88 \\
\hline $\begin{array}{l}\text { 2. The policy distinguishes bullying from other aggressive be- } \\
\text { haviors. }\end{array}$ & 49 & 0.88 & 7 & 0.88 \\
\hline $\begin{array}{l}\text { 3. The policy mentions verbal bullying (threats, insults, taunt- } \\
\text { ing). }\end{array}$ & 33 & 0.59 & 6 & 0.75 \\
\hline $\begin{array}{l}\text { 4. The policy mentions social or relational bullying (rumors, } \\
\text { social exclusion). }\end{array}$ & 31 & 0.55 & 6 & 0.75 \\
\hline 5. The policy mentions physical bullying (hitting, kicking). & 33 & 0.59 & 6 & 0.75 \\
\hline $\begin{array}{l}\text { 6. The policy mentions cyberbullying (e-mails, text messages, } \\
\text { and social networking sites). }\end{array}$ & 34 & 0.61 & 4 & 0.50 \\
\hline $\begin{array}{l}\text { 7. The policy mentions bullying because of sexual orientation } \\
\text { (homophobic behavior). }\end{array}$ & 29 & 0.52 & 2 & 0.25 \\
\hline 8. The policy mentions gender-based bullying. & 28 & 0.50 & 3 & 0.38 \\
\hline $\begin{array}{l}\text { 9. The policy mentions bullying of a sexual nature (nasty sex- } \\
\text { ual innuendoes, inappropriate touching). }\end{array}$ & 9 & 0.16 & 2 & 0.25 \\
\hline 10. The policy mentions bullying due to disabilities. & 28 & 0.50 & 2 & 0.25 \\
\hline $\begin{array}{l}\text { 11. The policy mentions religion-based bullying (diminishing } \\
\text { someone's faith or religious belief). }\end{array}$ & 28 & 0.50 & 3 & 0.38 \\
\hline $\begin{array}{l}\text { 12. The policy contains a statement that bullying behavior will } \\
\text { not be tolerated. }\end{array}$ & 43 & 0.77 & 6 & 0.75 \\
\hline
\end{tabular}


Table 1: Antibullying Content (mean in bold, standard deviation in brackets) in Ontario and Saskatchewan School Board and Division Policies (continued)

\begin{tabular}{|c|c|c|c|c|}
\hline \multirow[t]{2}{*}{ Criterion } & \multicolumn{2}{|c|}{ Ontario $(\mathrm{n}=56)$} & \multicolumn{2}{|c|}{ Saskatchewan $(\mathrm{n}=8)$} \\
\hline & \# of items & Mean & \# of items & Mean \\
\hline Establishing a positive school climate ( 9 criterions) & $\begin{array}{c}32 \\
(12.12)\end{array}$ & $\begin{array}{l}0.57 \\
(0.22)\end{array}$ & $\begin{array}{c}3.7 \\
(2.33)\end{array}$ & $\begin{array}{c}0.47 \\
(0.29)\end{array}$ \\
\hline $\begin{array}{l}\text { 1. All schools in the board or division are required to develop } \\
\text { and implement antibullying plans. }\end{array}$ & 41 & 0.73 & 6 & 0.75 \\
\hline $\begin{array}{l}\text { 2. The policy requires schools to take specific measures to cre- } \\
\text { ate a collaborative school climate. }\end{array}$ & 42 & 0.75 & 5 & 0.63 \\
\hline $\begin{array}{l}\text { 3. Schools are required to incorporate positive conflict resolu- } \\
\text { tion strategies, bullying education, or the preservation of } \\
\text { healthy relationships in classroom instruction. }\end{array}$ & 40 & 0.71 & 4 & 0.50 \\
\hline $\begin{array}{l}\text { 4. The policy requires schools to present opportunities for stu- } \\
\text { dents to participate in bystander intervention training or in } \\
\text { leadership initiatives. }\end{array}$ & 37 & 0.66 & 4 & 0.50 \\
\hline $\begin{array}{l}\text { 5. The policy requires schools to provide opportunities for } \\
\text { teachers, administrators, and other adults involved with the } \\
\text { students in the school setting to participate in bullying inter- } \\
\text { vention and prevention training. }\end{array}$ & 44 & 0.79 & 3 & 0.38 \\
\hline $\begin{array}{l}\text { 6. The policy mentions any of encouraging co-operative be- } \\
\text { havior, rewarding good behavior, improving school climate, or } \\
\text { creating a safe environment. }\end{array}$ & 54 & 0.96 & 8 & 1.0 \\
\hline $\begin{array}{l}\text { 7. The policy shows sensitivity to racial or ethnic minorities, } \\
\text { cultural groups, or other special education needs. }\end{array}$ & 26 & 0.46 & 1 & 0.13 \\
\hline 8. The policy mentions training for parents on bullying. & 13 & 0.23 & 2 & 0.25 \\
\hline $\begin{array}{l}\text { 9. The policy requires schools to assess the school climate } \\
\text { through anonymous surveys of staff, students, and parents. }\end{array}$ & 27 & 0.48 & 1 & 0.13 \\
\hline $\begin{array}{l}\text { Dissemination, Monitoring and Review of Policy ( } 4 \\
\text { criterions) }\end{array}$ & $\begin{array}{c}45 \\
(6.06) \\
\end{array}$ & $\begin{array}{c}0.81 \\
(0.11)\end{array}$ & $\begin{array}{c}5.8 \\
(1.50) \\
\end{array}$ & $\begin{array}{c}0.72 \\
(0.19) \\
\end{array}$ \\
\hline $\begin{array}{l}\text { 1. The policy is readily available to parents, students, or mem- } \\
\text { bers of the broader community. }\end{array}$ & 51 & 0.91 & 8 & 1.0 \\
\hline $\begin{array}{l}\text { 2. A plan is mentioned for the monitoring and review of the } \\
\text { antibullying policy. }\end{array}$ & 44 & 0.79 & 5 & 0.63 \\
\hline $\begin{array}{l}\text { 3. The policy mentions performance indicators, or mentions } \\
\text { how survey data will be used to verify the effectiveness of the } \\
\text { policy. }\end{array}$ & 37 & 0.66 & 5 & 0.63 \\
\hline $\begin{array}{l}\text { 4. The policy mentions the necessity of periodic review and } \\
\text { updating of the antibullying policy. }\end{array}$ & 48 & 0.86 & 5 & 0.63 \\
\hline
\end{tabular}




\begin{tabular}{|c|c|c|c|c|}
\hline \multirow[t]{2}{*}{ Criterion } & \multicolumn{2}{|c|}{ Ontario $(n=56)$} & \multicolumn{2}{|c|}{ Saskatchewan $(\mathrm{n}=8)$} \\
\hline & \# of items & Mean & \# of items & Mean \\
\hline $\begin{array}{l}\text { Reporting and Responding to Bullying (10 criteri- } \\
\text { ons) }\end{array}$ & $\begin{array}{c}27.6 \\
(10.86) \\
\end{array}$ & $\begin{array}{r}0.49 \\
(0.19) \\
\end{array}$ & $\begin{array}{c}5.1 \\
(2.18) \\
\end{array}$ & $\begin{array}{c}0.64 \\
(0.27) \\
\end{array}$ \\
\hline $\begin{array}{l}\text { 1. The policy mentions the creation of a safe schools team or } \\
\text { crisis response team to address bullying behavior. }\end{array}$ & 41 & 0.73 & 2 & 0.25 \\
\hline $\begin{array}{l}\text { 2. The policy requires schools to establish measures to help } \\
\text { students who have been victims of bullying, who have victim- } \\
\text { ized another students, and for bystanders who have witnessed } \\
\text { bullying. }\end{array}$ & 27 & 0.48 & 4 & 0.50 \\
\hline $\begin{array}{l}\text { 3. The policy requires schools to develop safe reporting proto- } \\
\text { cols for bullying behavior. }\end{array}$ & 39 & 0.70 & 2 & 0.25 \\
\hline $\begin{array}{l}\text { 4. The policy requires the assignment of responsibility to a } \\
\text { member of the school community for the recording and moni- } \\
\text { toring of bullying behavior. }\end{array}$ & 20 & 0.36 & 7 & 0.88 \\
\hline $\begin{array}{l}\text { a5. The policy requires a response to bullying behavior that } \\
\text { takes into consideration the nature and severity of incidents. }\end{array}$ & 46 & 0.82 & 7 & 0.88 \\
\hline $\begin{array}{l}\text { 6. The policy states what victims of bullying should do (tell a } \\
\text { teacher; more specific that just 'deal promptly'). }\end{array}$ & 16 & 0.29 & 6 & 0.75 \\
\hline $\begin{array}{l}\text { 7. The policy mentions follow-up to see if sanctions applied } \\
\text { for bullying behavior were effective. }\end{array}$ & 15 & 0.27 & 4 & 0.50 \\
\hline $\begin{array}{l}\text { 8. The policy mentions actions to be taken in cases of persis- } \\
\text { tent bullying. }\end{array}$ & 26 & 0.46 & 7 & 0.88 \\
\hline $\begin{array}{l}\text { 9. The policy mentions actions that teachers and staff (lunch- } \\
\text { room supervisors, custodians) should take in response to bul- } \\
\text { lying (more specific than "all staff"). }\end{array}$ & 26 & 0.46 & 8 & 1.0 \\
\hline $\begin{array}{l}\text { 10. The policy mentions actions that bystanders should take if } \\
\text { they witness bullying. }\end{array}$ & 20 & 0.36 & 4 & 0.50 \\
\hline Involving the Broader Community & 31.8 & 0.57 & 5.3 & 0.66 \\
\hline$(4$ criterions $)$ & $(15.17)$ & $(0.27)$ & $(3.10)$ & $(0.39)$ \\
\hline $\begin{array}{l}\text { 1. The policy mentions the issue of bullying happening on the } \\
\text { way to and from school. }\end{array}$ & 13 & 0.23 & 1 & 0.13 \\
\hline $\begin{array}{l}\text { 2. The policy discusses when and how parents will be in- } \\
\text { formed of bullying. }\end{array}$ & 37 & 0.66 & 8 & 1.0 \\
\hline $\begin{array}{l}\text { 3. The policy is systemic and involves members of the broader } \\
\text { community. }\end{array}$ & 49 & 0.88 & 7 & 0.88 \\
\hline $\begin{array}{l}\text { 4. The specific role of community members (youth, family, } \\
\text { service providers) in bullying intervention and prevention is } \\
\text { clearly described (more specific than "all community members } \\
\text { will be involved"). }\end{array}$ & 28 & 0.50 & 5 & 0.63 \\
\hline Total: 39 criterions & 33.4 & 0.60 & 4.7 & 0.59 \\
\hline
\end{tabular}




\section{Policy Development Frameworks and Extent of Policy Content}

Before presenting the extent of policy application in the frameworks, mention should be made of the small sample of policies obtained from Saskatchewan. The low response rate in this province raises questions about the validity of the ensuing results. The small number of policies that focus uniquely on bullying in Saskatchewan, despite the presence of the SABS, suggests a quandary in the interpretation of the framework by school division officials. In light of the fact that a number of school divisions had student-to student harassment policies, this seems to imply that bullying and harassment are perceived as unequivocal and that harassment policies are deemed sufficient to address both issues. Nonetheless, the overall percentage of proficient policy practices contained in Saskatchewan antibullying policies (59\%) is still sufficiently elevated to consider these documents in the analysis of results (Smith et al. 2008, reported 40\% of overall policy content). The author also deemed it beneficial to verify the extent of application of guidelines for developing antibullying policy by comparing two levels of resulting policy implementation, as little research has been conducted in this regard. For this reason, an analysis of Saskatchewan antibullying policies was undertaken despite the low response rate in this province.

The analysis of policies reflected particular trends in terms of antibullying content. To follow the Smith et al. (2008) interpretation, a criterion was considered highly satisfied if $95 \%$ of more of the school boards or divisions included the criterion, moderately satisfied in policy content if it was found in $50 \%-94 \%$ of policies, and marginally satisfied if less than $49 \%$ of school boards and divisions included the criterion.

Almost all categories had overall moderate criterion satisfaction in Ontario and Saskatchewan. For the first category on the definition of bullying behaviors, both provinces had moderate scores in presenting an overall definition of bullying, in distinguishing bullying from other aggressive behaviors, and in mentioning verbal, physical, social-relational, and cyberbullying. In Ontario, however, the mention of bullying due to sexual orientation, gender, special needs or religious beliefs was moderate, where in
Saskatchewan mention of these potential bullying causes was low. In both provinces, mention was low of bullying of a sexual nature, and moderate in the inclusion of a statement that bullying will not be accepted on school property.

In the second category, which presented the establishing of a positive school climate, overall criterion satisfaction was moderate in Ontario and low in Saskatchewan. Nonetheless, both provinces scored high on policies mentioning the promotion of positive and collaborative behaviors and improving the school climate. On the other hand, both provinces scored moderately on requiring schools to establish bullying intervention and prevention programs, taking specific measures to create a positive school climate, and incorporating bullying education and leadership initiatives to the curriculum. Ontario also scored moderately on providing education opportunities for teachers, staff, and others involved with the students, where Saskatchewan scored low in this regard. Both provinces scored low in mentioning sensitivity to diversity, providing training opportunities for parents in regards to bullying, and requiring the assessment of the school climate through anonymous surveys.

The third category, dissemination, monitoring and review of policy, had the most elevated criterion content in Ontario and Saskatchewan. Criterion satisfaction was $100 \%$ in Saskatchewan for making the policy readily available to parents and the broader community, and was moderate in Ontario. Nonetheless, criterion satisfaction was moderate in both provinces for all other criterions, namely the establishment of monitoring, review, and periodic updating of the policy as well as a specific course of action to proceed in the review.

In the fourth category, reporting and responding to bullying, overall criterion satisfaction was low in Ontario and moderate in Saskatchewan. In Ontario, a moderate response was obtained for the creation of safe school teams, the development of safe reporting protocols, and a progressive response to bullying. All other criterions had low satisfaction. In Saskatchewan, a high criterion satisfaction was found for the explication of the roles of teachers and staff in response to bullying, and moderate criterion satisfaction was found for requiring schools to help bullies, victims, and bystanders, assigning responsibility for 
the documentation of bullying, a progressive response to bullying, actions for victims and bystanders in situation of bullying, as well as follow-up for applied sanctions and courses of action in cases of persistent bullying.

For the final category, involving the broader community, both provinces had moderate overall criterion inclusion. Both provinces scored low in mentioning bullying on the way to and from school, and moderate in involving the broader community and defining their specific roles. Ontario scored moderately in informing parents of bullying whereas Saskatchewan scored high for this criterion.

\section{Discussion}

\section{Bridging the Gap between Policy Content and Effective Antibullying Practices}

There are a number of practical applications to extrapolate from the Ontario and Saskatchewan bullying intervention and prevention representations when developing educational policies to reduce bullying in schools. First, the presence of a framework such as the SABS and the PPM with mandatory inclusion in province-wide school board and division bullying policies confirms that antibullying endeavors are obligated and will be undertaken, hypothetically, in all provincial public and catholic schools, in all school authorities, and in all educational hospitals. On the other hand, as is attested by the low response rate in Saskatchewan, the presence of a framework does not mean that all educational authorities will automatically develop antibullying policies to counter school bullying. It appears that the perception of bullying and harassment is dichotomous, which should be addressed if clear and concise bullying policies are to be developed and implemented appropriately.

Furthermore, as findings of this study suggest, there is a discernible gap between elements of the framework and actual insertion of particular aspects of the PPM (60\%) and SABS (59\%) in individual board policies. Both provinces had the possibility of flexibility in regional adaptation of elements from the PPM and SABS. The value of this flexibility could potentially be a downfall in the sense that crucial elements of bullying intervention can then become neglected if they are perceived to be unnecessary in an educational setting. It is, however, a downfall that can be addressed through a systematic evaluation of the effectiveness of antibullying policies implemented in a school system, which was elevated in the policies studied in this paper. While both provincial frameworks propose such review processes, the aforementioned gap between the PPM and SABS and the content of policies presents the necessity of putting into practice additional protocols beyond evaluating the substance of policies in order to ensure that their content is really reducing school bullying. Swearer and Doll (2001) support this affirmation in their indication that numerous bullying intervention programs are developed following a public outcry for justice, but the urgency of implementation causes these programs to be put into action in the absence of scientific validation. Evaluating the effectiveness of policy also diminishes the possibility of omission of crucial elements of bullying intervention and prevention under the pretext of nonapplicability to a particular setting.

Another important consideration to derive from these policies is the fact that intervention and prevention should be systemic, and should extend beyond the classroom (Olweus, 2004). In fact, while a moderate percentage of policies in Ontario and Saskatchewan solicited involvement from sources outside of the school setting, a smaller percentage of policies actually indicated the specific role that these agencies should occupy in bullying intervention and prevention. Also marginal in both provinces was the mention of bullying happening on the way to and from school. Clearly defining the roles of community partners as well as intervention for bullying occurring outside school grounds are definite areas for further research because they constitute a distribution of responsibility and accountability when bullying occurs, where everyone is aware of their capacity in intervention and prevention. If schools fail to research the availability of community resources, they may also neglect to incorporate these resources to remediate bullying incidents, thus missing out on the capabilities of experts in the community trained to assist in bullying cases.

Certain limitations of the PPM and SABS must also be discussed. First, researchers do not agree on a universal qualification of bullying since perceptions vary as to its definite constitution (Rigby et al., 2004; 
Rigby, 2008). Nonetheless, both provincial frameworks attempt to establish parameters to define this phenomenon. Yet, policy content in both provinces was moderate in defining different types of bullying. In contrast, some philosophers and psychologists have theorized that conflicts of a certain nature correspond to a natural developmental process and do not necessarily characterize bullying (Erikson, 1980; Honneth, 1995). If intervention is to be successful, it seems that bullying should be more clearly defined in policy. Furthermore, isolated harrying incidents between peers sometimes leave their mark, and in fact, unhealthy or unresolved peer conflicts often incite subsequent bullying. The nomenclatures in the provincial frameworks do not account for natural conflicts whereas a logical first step to bullying prevention seems to be the address of these conflicts before their escalation to worse maltreatment between peers.

Moreover, while both provincial frameworks mention group and bystander interventions, they neglect to impose processes to ensure that valuable bullying intervention can take place even in the absence of parental support. Research has nonetheless uncovered links between variables in parenting practices and exhibition of aggressive behavior (An \& Cooney, 2004; Idsoe, Solli, \& Cosmovici, 2008). Rigby (2008) further affirms that children who have difficulty relating to members of their family are likely to experience these same difficulties when relating to their peers. Further research would be warranted in this case in order to determine ways to incorporate this contingency into policy in terms of effective antibullying practices that can take place in situations where parents are not supportive of the interventions attempted by the school.

\section{Conclusion}

It is unmistakably difficult to ascribe precedence to specific fundamentals of bullying intervention and prevention. Opinions may differ as to specific criterion that should be included or omitted from a prioritized list of best practices. In fact, as has been stated above, a variety of bullying intervention and prevention programs have been developed and implemented using an assortment of structures, yet there has been little consistency in results (Sanchez et al., 2001; Howard, Horne, \& Joliff, 2001; Pepler et al., 2004). Where one program may have high success rates in a particular setting, another similar program may have lesser rates of success in a different but comparable setting. As a result, bullying intervention and prevention in schools can sometimes subsist as a sequence of trial and error rather than a panacea. A logical next step seems to be research into the correlation between school policies and the prevalence of bullying in schools, with a subsequent re-tailoring of policies to address problematic areas identified. Another logical possibility for further research is an analysis of discourse between individuals who are on the front lines of implementation of policy components to determine their conception of strengths and limitations of the bullying intervention and prevention measures undertaken in their particular school.

Diagnostic assessment followed by remedial action seems to be a common, and effective, trend in education when working towards educational change. As policy becomes diluted through various stages of implementation, there is potential for the omission of significant elements crucial to bullying intervention and prevention in resulting school endeavors. However, the fact that the PPM and the SABS have been established with such clear and consistent guidelines is an important first step to ensuring that all Ontario and Saskatchewan schools are taking action to reduce bullying, thus ensuring quality educational experiences as well as the overall emotional, social and psychological well-being of learners.

\section{References}

An, J., \& Cooney, T. (2004). Psychological wellbeing in adulthood: The effects of received disciplines from parents in childhood. The Gerontologist, 44, 275.

Beaty, L., \& Alexeyev, E. (2008). The problem of school bullies: What the research tells us. Adolescence, 43, 1-9.

Bloom, A. (2008). Bullying policies miss the point. Times Educational Supplement, 4783, 30.

Caruso, N. (2009). What would you do if... your board were considering an antibullying policy? American School Board Journal. 
Cohen, J. (1960). A coefficient of agreement for nominal scales. Educational and Psychological Measurement, 20, 37-46.

Coloroso, B. (2002). The bully, the bullied, and the bystander. Toronto, Ontario: HarperCollins Publishers Ltd.

Craig, W.M., \& Harel, Y. (2004). Bullying, physical fighting, and victimization. In C. Currie, C. Roberts, A. Morgan, R. Smith, W. Settertobulte, O. Samdal et al. (Eds.), Health Behaviour in Schoolaged Children (HBSC) study: international report from the 2001/2002 survey. Copenhagen, Denmark: World Health Organization.

Daniel, Y. \& Bondy, K. (2008). Safe schools and zero tolerance: policy, programs and practice in Ontario. Canadian Journal of Educational Administration and Policy, 70, 1-20.

Department for Children, Schools, and Families (DfES), (2002). Bullying: Don't suffer in silence. An antibullying pack for schools. London: DfES.

Education Act, E-0.2 \& \& 38, 40 (1997).

Erikson, E. (1980). Identity and the life cycle. New York, New York: W.W. Norton \& Company.

Espelage, D., \& Asidao, C. (2001). Conversations with middle school students about bullying and victimization: Should we be concerned? In Geffner, R., Loring, M., \& Young, C. (Eds.) Bullying Behavior: Current Issues, Research, and Interventions (pp. 49-62). Binghamton, New York: The Haworth Maltreatment \& Trauma Press.

Glover, D., Cartwright, N., Gough, G., \& Johnson, M. (1998). The introduction of antibullying policies: Do policies help in the management of change? School Leadership \& Management, 18, 89105.

Hamarus, P. \& Kaikkonen, P. (2008). School bullying as a creator of pupil peer pressure. Educational Research, 50, 343-345.

Honneth, A. (1995). The struggle for recognition: The moral grammar of social conflicts. Cambridge, Massachusetts: The MIT Press.

House of Commons. (2007). House of Commons Education and Skills Committee: Bullying: Third report of session 2006-2007. London: The Stationery Office.
Howard, N., Horne, A., \& Joliff, D. (2001). Selfefficacy in a new training model for the prevention of bullying in schools. In Geffner, R., Loring, M., \& Young, C. (Eds.). Bullying Behavior: Current Issues, Research, and Interventions (pp. 181-191). Binghamton, New York: The Haworth Matreatment \& Trauma Press.

Idsoe, T., Solli, E., \& Cosmovici, E. (2008). Social psychological processes in family and school: More evidence on their relative etiological significance for bullying behavior. Aggressive Behavior, 34, 460-474.

Olweus, D. (2004). The Olweus bullying prevention programme: Design and implementation issues and a new national initiative in Norway. In Smith, P., Pepler, D., \& Rigby, K. (Eds.), Bullying in Schools: How Successful Can Interventions Be? (pp. 13-36. Cambridge, New York: Cambridge University Press.

Olweus, D., Limber, S., \& Mihalic, S. (1999).Blueprints for violence prevention: The bullying prevention program. Boulder, Colorado: Center for the Study and Prevention of Violence.

O'Moore, A., \& Minton, J. (2005). Evaluating the effectiveness of an antibullying programme in primary schools. Aggressive Behavior, 31, 609-622.

Ontario Ministry of Education. (n.d.). Education Facts. Retrieved October 31, 2008, from http://www.edu.gov.on.ca/eng/educationFacts.htm

Ontario Ministry of Education. (2007). Bullying prevention and intervention: Policy/Program Memorandum No. 144. Retrieved July 2, 2008, from http://www.edu.gov.on.ca/extra/eng/ppm/144.pdf

Ontario Ministry of Education. (2009). Bullying prevention and intervention: Policy/Program Memorandum No. 144. Retrieved July 2, 2008, from http://www.edu.gov.on.ca/extra/eng/ppm/144.pdf

Pepler, D., Craig, W., O'Connell, P., Atlas, R., \& Charach, A. (2004). Making a difference in bullying: Evaluation of a systemic school-based programme in Canada. In Smith, P., Pepler, D., and Rigby, K. (Eds.) Bullying in schools: how successful can interventions be? (pp. 125-139). Cambridge, New York: Cambridge University Press. 
Rigby, K. (2002). A meta-evaluation of methods and approaches to reducing bullying in pre-schools and in early primary school in Australia, Commonwealth Attorney-General's Department, Canberra.

Rigby, K. (2008). Children and bullying: how parents and educators can reduce bullying at school. Malden, Massachusetts: Blackwell Publishing.

Rigby, K., Smith, P., \& Pepler, D. (2004). Working to prevent school bullying: Key issues. In Smith, P., Pepler, D. and Rigby, K. (Eds.) Bullying in schools: how successful can interventions be? (pp. 1-12). Cambridge, New York: Cambridge University Press.

Sanchez, E., Robertson, T., Lewis, C., Rosenbluth, B., Bohman, T., \& Casey, D. (2001).

Preventing bullying and sexual harassment in elementary schools: The expect respect model. In Geffner, R., Loring, M., \& Young, C. (Eds.) Bullying Behavior: Current Issues, Research, and Interventions (pp. 157-180). Binghamton, New York: The Haworth Matreatment \& Trauma Press.

Saskatchewan Learning. (2005). Antibullying strategy. Saskatchewan: Government of Saskatchewan.

Saskatchwan Learning. (2006). Caring and respectful schools - Bullying prevention: a model policy. Saskatchewan: Government of Saskatchewan.

Skerrett, A. (2009). Melting pot influences on secondary English curriculum policy. International Journal of Educational Policy and Leadership, 4 (11), 112.
Smith, P., Smith, C., Osborn, R., \& Samara, M. (2008). A content analysis of school antibullying policies: Progress and limitations. Educational Psychology in Practice, 24, 1-12.

Soutter, A., \& McKenzie, A. (2000). The use and effects of antibullying and anti-harassment policies in Australian schools. School Psychology International, 21, 96-105.

Swearer, S., \& Doll, B. (2001). Bullying in schools: An ecological framework. In Geffner, R., Loring, M., \& Young, C. (Eds.), Bullying Behavior: Current Issues, Research, and Interventions (pp. 7-23). Binghamton, New York: The Haworth Maltreatment \& Trauma Press.

Swearer, S., Limber, S. \& Alley, R. (2009). Developing and implementing an effective antibullying policy. In Swearer, S., Espelage, D., \& Napolitano, S. (Eds.), Bullying Prevention and Intervention: Realistic Strategies for Schools (pp. 39-52). New York, New York: The Guilford Press.

Woods, S., \& Wolke, D., (2003). Does the content of antibullying policies inform us about the prevalence of direct and relational bullying behaviour in primary schools? Educational Psychology, 23, 381-398.

IJEPL is a joint publication of the Association for Supervision and Curriculum Development, the Faculty of Education at Simon Fraser University, and the College of Education and Human Development at George Mason University. By virtue of their appearance in this open access journal, articles are free to use, with proper attribution, in educational and other non-commercial settings 90 days after initial publication. Copyright for articles published in IJEPL is retained by the authors. More information is available on the IJEPL Web site: http://www.ijepl.org 